\title{
Adherence of Staphylococcus aureus to cultured epidermal cells during differentiation
}

\author{
Y. MIYAKE, M. SUGAI, A.KOHADA*, S. MINAGIt and H. SUGINAKA \\ Department of Microbiology, Hiroshima University School of Dentistry, 1-2-3 Kasumi, Minami-ku, Hiroshima \\ 734, Japan
}

\begin{abstract}
Summary. The adherence of clinical isolates of Staphylococcus aureus to cultured mouse epidermal cells was studied. Adherence of the isolates to the cells varied from strain to strain. When epidermal cell differentiation was induced by raising the calcium concentration in the medium, three out of 10 strains tested adhered better to calcium-induced differentiated cells than to undifferentiated cells, and one strain demonstrated higher adherence to undifferentiated cells than to differentiated cells. No significant difference between the adherences to both types of epidermal cells was observed with the other six strains. No relationship was observed between adherence and surface hydrophobicity with bacterial cells. Lipoteichoic acid and $\mathrm{N}$-acetyl sugars caused limited inhibition of adherence. The adherence assay method employed in this study is useful for investigating the effects of epidermal cell differentiation on bacterial adherence in vitro.
\end{abstract}

\section{Introduction}

Staphylococcus aureus is the most common pathogen causing skin and soft tissue infections. Bacterial adherence is an essential step in initiating infection and has been extensively investigated, together with the factors which influence it. $S$. aureus lipoteichoic acid (LTA) and teichoic acid has been reported to play a role in bacterial adherence (Aly et al., 1980; Carruthers and Kabat, 1983; Aly and Levit, 1987). The interactions of $S$. aureus with fibronectin, serum spreading factor, collagen and laminin, which are constituents of the extracellular matrices of host cells, have also been studied (Rydén et al., 1983; Lopes et al., 1985; Fuquay et al., 1986; Holderbaum et al., 1986; Maxe et al., 1986; Aly and Levit, 1987). The effects of host cell surface characteristics on $S$. aureus adherence were also reported. $S$. aureus is more commonly isolated from patients with atopic dermatitis than from healthy controls (Leyden et al., 1974; Aly et al., 1977) and it has been found to adhere well to nasal and skin cells of patients (Bibel et al., 1982).

These studies were performed with exfoliated

Received 25 May 1989; accepted 10 Oct. 1989.

*Present address: Department of Removable Prosthodontics, Hiroshima University School of Dentistry, Hiroshima 734, Japan.

†Present address: Department of Removable Prosthodontics, Okayama University Dental School, Okayama 700, Japan. epithelial cells as substrates in an adherence assay. Such cells are terminally differentiated and shed from the most exposed position of the epidermal layer or epithelial lining, in which they play a role as a primary protective barrier against the external world. Bibel et al. (1982) using scraped nasal epidermal cells, suggested the importance of keratinisation in the adherence of $S$. aureus. Epidermis is a composite of several layers that differ in their levels of differentiation, and epidermal cells change dramatically in morphology during the differentiation process. Therefore, it is of great interest to understand the mode of expression of surface characterisation influencing the adherence of $S$. aureus.

In the present study, we employed a mouse epidermal cell culture as an in-vitro model of differentiation and studied the effect of differentiation on staphylococcal adherence to epidermal cells. Rodents are often used as experimental models to study human infectious skin diseases (Ray and Wuepper, 1976; Ray and Payne, 1988). Furthermore, the mouse epidermal cell culture used has been well established as a primary culture system, and cell differentiation can be controlled by changing the calcium concentration in the medium (Hennings et al., 1980). Cells cultured in a low calcium medium $(0.05 \mathrm{~mm})$ grow without differentiation, and an increase in the culture medium calcium concentration induces cell differentiation. Cells cultured by this method may be useful in 
investigating the effect of host cell differentiation on bacterial adherence in vitro.

\section{Materials and methods}

\section{Bacteria and culture conditions}

S. aureus FDA 209P and 10 clinical isolates of $S$. aureus were used in this study. The clinical isolates were kindly provided by Biology Laboratories, Central Research Division, Takeda Chemical Industries Ltd, Osaka, Japan. Four strains of strain numbers with letter $\mathbf{M}$, four strains with letter $U$ and two strains with letter $O$ were isolated from pus samples, urine samples and other samples, respectively. A stock culture was grown overnight in Trypticase Soy Broth (TSB; BBL Microbiology Systems, Cockeysville, MD, USA). This culture was inoculated into fresh TSB to give an optical density at $660 \mathrm{~nm}$ of $0 \cdot 1$ and incubated at $37^{\circ} \mathrm{C}$ for $3-4 \mathrm{~h}$. The bacterial cells were harvested by centrifugation and washed in $0.01 \mathrm{M}$ phosphate buffered saline (PBS; $\mathrm{pH} 7 \cdot 4$, with $\mathrm{Ca}^{++}$and $\mathrm{Mg}^{++}$). The cells were then dispersed by means of mild sonication, re-suspended in PBS, and adjusted to a concentration of $1 \times 10^{8}$ cells $/ \mathrm{ml}$ by counting with a Coulter Counter (model ZM, Coulter Electronics Ltd, USA, FL) (Miyake et al., 1989).

\section{Extraction of LTA}

For extraction of lipoteichoic acid (LTA), $500 \mathrm{ml}$ of the overnight culture was inoculated into $4.5 \mathrm{~L}$ of fresh TSB and incubated for 4-5 h. Cells were harvested by centrifugation, washed in purified water, and then used for the preparation of LTA as previously described (Miyake et al., 1989). Briefly, washed $S$. aureus cells were treated overnight with chloroform: methanol $(1: 1 \mathrm{v}: \mathrm{v})$ at room temperature and centrifuged. The cells were then treated with methanol $45 \% \mathrm{v} / \mathrm{v}$ at room temperature for $1 \mathrm{~h}$. The aqueous phase was then removed, dialysed against purified water and dried, and the deposit was dissolved in water. The material was separated by chromatography on a Sepharose 6B column $(2 \cdot 2 \times$ $35.5 \mathrm{~cm}$; Pharmacia Fine Chemicals AB, Uppsala, Sweden), and fractions were monitored by measuring glycerol and phosphorus concentrations. Glycerol concentration was measured by the method of Hanahan and Olley (1958). Briefly, $0.1 \mathrm{ml}$ of $10 \mathrm{~N} \mathrm{H}_{2} \mathrm{SO}_{4}$ and $0.5 \mathrm{ml}$ of $0.1 \mathrm{M}$ sodium periodate were added to $2.0 \mathrm{ml}$ of sample. After standing at room temperature for $30 \mathrm{~min}, 0.5 \mathrm{ml}$ of sodium bisulphate $10 \%$ was added; $1 \mathrm{ml}$ of this mixture was mixed with $5 \mathrm{ml}$ of chromotropic acid and heated for $30 \mathrm{~min}$ in boiling water. The reaction mixture was cooled and $0.5 \mathrm{ml}$ of half saturated thiourea was added, and then the absorbance at $570 \mathrm{~nm}$ was read spectrophotometrically. Phosphorus concentration was assayed by the method of Lowry et al. (1954). The sample was added to $0.8 \mathrm{~N} \mathrm{HClO}_{4}$ in $10 \mathrm{~N} \mathrm{H}_{2} \mathrm{SO}_{4}$ and heated at $165^{\circ} \mathrm{C}$ for $2 \mathrm{~h}$. To the mixture, $50 \mu \mathrm{l}$ of ammonium molybdate $0.25 \%$ in
$0.1 \mathrm{~N}$ sodium acetate and ascorbic acid were added. After incubation at $37^{\circ} \mathrm{C}$ for $1.5 \mathrm{~h}$ absorbance at $820 \mathrm{~nm}$ was read. LTA fractions were combined and then purified by chromatography with a CNBr-Sepharose 4B column $(1.6 \times 7.8 \mathrm{~cm}$, Pharmacia) coupled with human serum albumin (Sigma Chemical Co., St Louis, MO, USA). Absorbed LTA was eluted with ethanol $50 \% \mathrm{v} / \mathrm{v}$ in $0.02 \mathrm{M}$ phosphate buffered saline, $\mathrm{pH} 7 \cdot 4$. A fraction with a ratio of glycerol: phosphorus of 1:1.09 was used for the inhibition assay.

\section{Preparation of mouse epidermal cell monolayer}

Epidermal cells were isolated from newborn CD-1 mouse skin and cultured under low calcium conditions as described previously (Hennings et al., 1980; Sugai et al., 1987) with some modifications. Briefly, epidermal cells were prepared from newborn mouse skin by a trypsin flotation procedure, and $5 \times 10^{5}$ cells were seeded on to a plastic cover slip (Celldesk ${ }^{\mathrm{TM}}$, Sumitomo Bakelite Company Ltd, Tokyo, Japan) and placed in a 24-well culture dish. Epidermal cells were selectively cultured as a monolayer in Eagle's Minimal Essential Medium (EMEM) without calcium and containing Chelex (BioRad Laboratories, Richmond, CA, USA)-treated fetal calf serum (FCS), $10 \% \mathrm{w} / \mathrm{v}$ in which the net calcium concentration was adjusted to $0.06-0.07 \mathrm{~mm}$ (low calcium medium). The medium was changed every $24 \mathrm{~h}$ during incubation.

To induce differentiation of epidermal cells, the culture medium was substituted with normal EMEM supplemented with FCS $10 \%$ and with a calcium concentration of $c .1 \mathrm{~mm}$ and then incubated.

\section{Adherence assay}

The adherence assay was performed as previously described (Miyake et al., 1989). Briefly, three cover slips, on which epidermal cells were cultured, were placed in a petri dish $(10 \times 35 \mathrm{~mm}$, Falcon $)$ and $3 \mathrm{ml}$ of the bacterial suspension was added to the dish. After incubation for $30 \mathrm{~min}$ at $37^{\circ} \mathrm{C}$ with gentle rotation $(60 \mathrm{rpm})$, the cover slips were removed from the dish, washed three times in PBS, dried in air and mounted on a glass slide. The slips were then fixed in ethanol and stained by Gram's method. Adherent bacterial cells in 10 fields, selected randomly (total $0.1 \mathrm{~mm}^{2}$ ), were counted on each slip by light microscopy, and the mean number (and SD) of adherent cells from three cover slips was calculated.

To determine the effect of LTA on adherence, an epidermal cell monolayer was treated with LTA $380 \mu \mathrm{g} /$ $\mathrm{ml}$ for $15 \mathrm{~min}$ at $37^{\circ} \mathrm{C}$. After washing in PBS, the monolayer was used for the adherence assay.

The effect of sugars on staphylococcal adherence was also determined. $N$-Acetyl neuraminic acid (NANA), $N$ acetyl-D-glucosamine (GlcNAc) (Sigma) and $N$-acetyl-Dgalactosamine (GalNAc, Aldrich Chemical Co. Milwaukee, WI, USA) were added to the bacterial suspension at a final concentration of $250 \mu \mathrm{g} / \mathrm{ml}$. 


\section{Measurement of contact angle}

The contact angles $(\theta)$ on the epidermal cell monolayer were measured under wet conditions by a vertical plate method (fig. 1), which is appropriate for evaluating the exact values of contact angles on hydrophilic surfaces (Minagi et al., 1986a). The contact angle of distilled water is calculated from the following equation:

$$
\sin \theta=1-\left(\rho \operatorname{gh}^{2} / 2 \gamma\right)
$$

where $\rho=$ density of liquid medium, $\mathrm{g}=$ gravity, $\mathrm{h}=$ height of modified capillary rise of liquid medium (fig. 1) and $\gamma=$ surface tension of liquid medium.

\section{Hydrophobicity}

Bacterial cell surface hydrophobicity was determined by adherence to hexadecane (Rosenberg et al., 1980; Minagi et al., 1986b). Briefly, $500 \mu \mathrm{l}$ of hexadecane was added to $2 \mathrm{ml}$ of the bacterial suspension in a small tube $(12 \times 105 \mathrm{~mm})$. The tube was mixed for $2 \mathrm{~min}$ vigorously, and the optical density at $660 \mathrm{~nm}$ was measured before and after mixing. The assay was performed in triplicate.

\section{Statistical analysis}

All comparisons of significance were by unpaired Student's $t$-test.

\section{Results}

Epidermal cells isolated from new-born mice were cultured in low calcium medium, and switch-

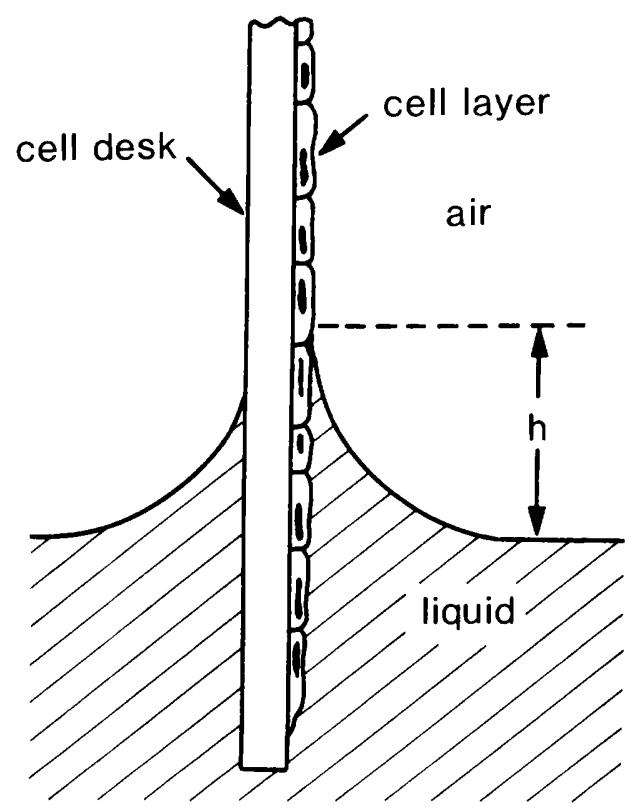

Fig. 1. Diagram of the vertical plate method, $h=$ height of modified capillary rise of liquid medium. ing to high calcium medium induced cell differentiation as reported previously (Hennings et al., 1980). Cells grown in low calcium medium formed a monolayer with a paving stone appearance and distinct intercellular spaces. Cells which were switched to high calcium medium and grown for $48 \mathrm{~h}$ became larger in size, had fewer intercellular spaces, and were stratified. The adherence of $S$. aureus 209P and the 10 clinical isolates to mouse epidermal cells maintained in low calcium medium and to those induced to differentiate is shown in table I. The adherence of isolates to either type of cell varied from strain to strain, and the reference strain 209P was the least adherent of all the strains used. Three out of the 10 isolates adhered better $(p<0.05)$ to cells which were induced to differentiate than to cells cultured in low calcium medium. One strain was more adherent $(p<0 \cdot 05)$ to cells cultured in low calcium medium than to those which were induced to differentiate. With the other six strains, there was no statistically significant difference in their adherence to differentiated and undifferentiated cells. The effect of epidermal cell differentiation on staphylococcal adherence was studied in detail with cells in different stages of differentiation (fig. 2a). Three isolates were examined for their adherence to epidermal cells incubated in a high calcium medium for 24,48 and $72 \mathrm{~h}$. It was observed that the longer the incubation period of epidermal cells in high calcium medium, the higher was the adherence of strain U-60, a highly adherent strain. Strain U-9-1, a moderately adherent strain, showed greater adherence to cells which were induced to differentiate and exhibited slightly increased adherence to epidermal cells with

Table I. Adherence of $S$. aureus clinical isolates to differentiated and undifferentiated cultured mouse epidermal cells

\begin{tabular}{l|ccc}
\hline & \multicolumn{3}{|c}{$\begin{array}{c}\text { Adherent cell number (SD) to } \\
\text { epidermal cells }\end{array}$} \\
$\begin{array}{l}\text { Strain } \\
\text { no. }\end{array}$ & $\begin{array}{l}\text { Undifferentiated } \\
\text { Differentiated }\end{array}$ & p-value \\
\hline U-59-1 & $2627(541)$ & $2702(319)$ & $0 \cdot 874$ \\
U-60 & $2320(340)$ & $3029(76)$ & 0.045 \\
M-1-141 & $1880(277)$ & $2596(246)$ & $0 \cdot 105$ \\
U-78-1 & $2064(206)$ & $2327(412)$ & $0 \cdot 463$ \\
M-1-144 & $1282(290)$ & $2281(193)$ & 0.015 \\
M-1-145 & $1453(89)$ & $1607(131)$ & $0 \cdot 240$ \\
U-9-1 & $918(44)$ & $1599(300)$ & 0.033 \\
M-1-143 & $1783(347)$ & $1475(202)$ & $0 \cdot 338$ \\
$0-28$ & $749(72)$ & $674(95)$ & $0 \cdot 349$ \\
$0-42$ & $828(35)$ & $627(89)$ & $0 \cdot 040$ \\
$209 P$ & $110(5)$ & $108(31)$ & 0.932 \\
& & & \\
\hline
\end{tabular}




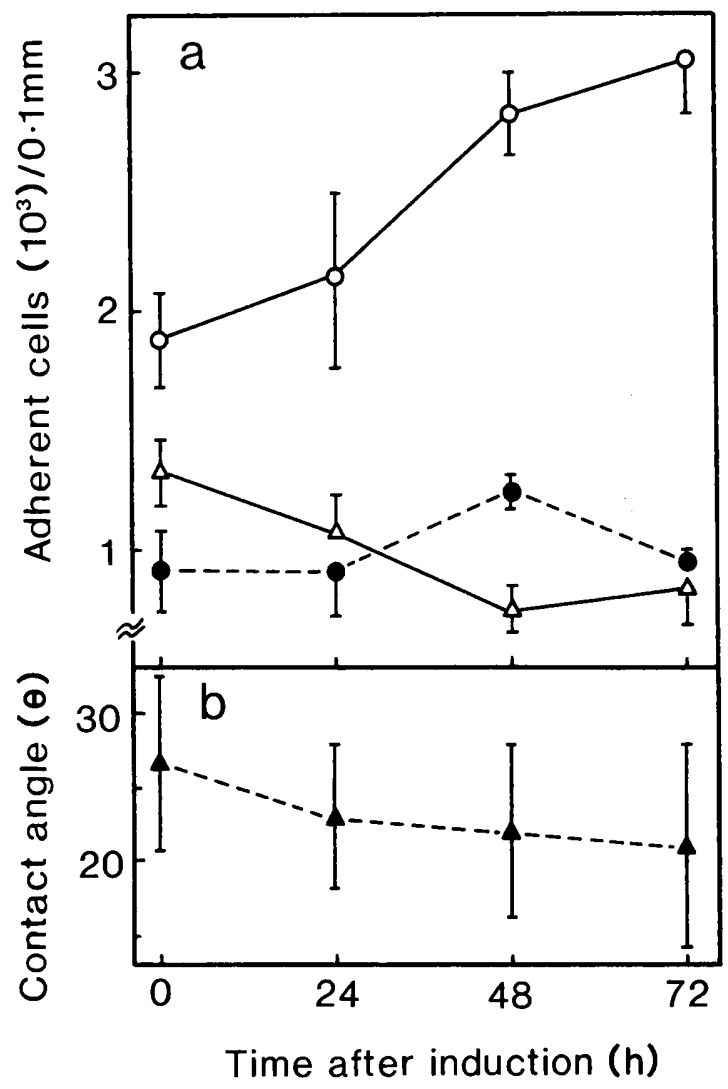

Fig. 2. Effect of epidermal cell differentiation on staphylococcal adherence and cell surface hydrophobicity. (a) Effect of incubation period in high calcium medium on the adherence of $S$. aureus clinical isolates; culture medium of epidermal cells was switched to high calcium medium and incubated for 24,48 and $72 \mathrm{~h}$, then the adherence of strains U-60 (o), U-9-1 (O) and O-42 $(\triangle)$ was determined. (b) Effect of incubation period in high calcium medium on surface hydrophobicity of cultured mouse epidermal cells; culture medium of epidermal cells was switched to high calcium medium and incubated for 24,48 and $72 \mathrm{~h}$, then contact angles were measured by the vertical method.

longer incubation in the high calcium medium. Strain O-42, which was more adherent to cells in low calcium medium, showed decreased adherence to differentiated epidermal cells. Contact angles of the epidermal cell surfaces in four stages were also measured (fig. 2b). No significant change in epidermal cell surface hydrophobicity was observed. Cell surface hydrophobicity of the isolates was measured by the adherence assay to $n$ hexadecane (table II). However, no correlation was observed between cell surface hydrophobicity and the adherence profile of $S$. aureus.

The effects of LTA and $N$-acetyl sugars on bàcterial adherence were studied (table III). Although LTA inhibited adherence to cells both in
Table II. Adherence of $S$. aureus clinical isolates to $n$ hexadecane

\begin{tabular}{l|c}
\hline Strain & \\
no. & Percentage adherence to hexadecane (SD) \\
\hline U-59-1 & $25 \cdot 8(6 \cdot 6)$ \\
U-60 & $31 \cdot 6(5 \cdot 2)$ \\
M-1-141 & $28 \cdot 3(2 \cdot 6)$ \\
U-78-1 & $29 \cdot 5(1 \cdot 6)$ \\
M-1-144 & $47 \cdot 0(1 \cdot 7)$ \\
M-1-145 & $30 \cdot 2(4 \cdot 1)$ \\
U-9-1 & $30 \cdot 0(2 \cdot 5)$ \\
M-1-143 & $17 \cdot 7(1 \cdot 0)$ \\
O-28 & $40 \cdot 6(2 \cdot 7)$ \\
O-42 & $12 \cdot 3(1 \cdot 8)$ \\
$209 P$ & $16 \cdot 4(1 \cdot 5)$ \\
\hline
\end{tabular}

Table III. Effect of LTA* and $N$-acetyl sugars $\dagger$ on staphylococcal adherence to cultured mouse epidermal cells

\begin{tabular}{|c|c|c|c|}
\hline \multirow[b]{2}{*}{ Strain } & \multirow[b]{2}{*}{ Treatment } & \multicolumn{2}{|c|}{$\begin{array}{l}\text { Percentage (of control) adherence } \\
\text { (SD) to epidermal cells }\end{array}$} \\
\hline & & Undifferentiated & Differentiated \\
\hline U-60 & $\begin{array}{l}\text { LTA } \\
\text { GalNAc } \\
\text { GlcNAc } \\
\text { NANA }\end{array}$ & $\begin{array}{l}74 \cdot 3(8 \cdot 5) \\
73 \cdot 0(6 \cdot 0) \\
93 \cdot 2(14 \cdot 6) \\
88 \cdot 4(9 \cdot 9)\end{array}$ & $\begin{array}{l}76 \cdot 7(4 \cdot 5) \\
73 \cdot 0(5 \cdot 7) \\
81 \cdot 5(4 \cdot 8) \\
77 \cdot 0(2 \cdot 9)\end{array}$ \\
\hline U-9-1 & $\begin{array}{l}\text { LTA } \\
\text { GalNAc } \\
\text { GlcNAc } \\
\text { NANA }\end{array}$ & $\begin{array}{r}82.8(15 \cdot 8) \\
124 \cdot 7(12 \cdot 6) \\
118 \cdot 5(16 \cdot 2) \\
96 \cdot 6(13.8)\end{array}$ & $\begin{array}{c}61.8(14.0) \\
104.8(8.6) \\
114.0(13.4) \\
80.4(9 \cdot 2)\end{array}$ \\
\hline $\mathrm{O}-42$ & $\begin{array}{l}\text { LTA } \\
\text { GalNAc } \\
\text { GlcNAc } \\
\text { NANA }\end{array}$ & $\begin{array}{c}79.5(11.5) \\
101.8(10 \cdot 7) \\
83.6(7.3) \\
76.9(7.5)\end{array}$ & $\begin{array}{c}61 \cdot 6(11 \cdot 9) \\
100 \cdot 9(8 \cdot 5) \\
127 \cdot 2(14 \cdot 1) \\
81 \cdot 0(19 \cdot 4)\end{array}$ \\
\hline
\end{tabular}

*Epidermal cells were treated with LTA $380 \mu \mathrm{g} / \mathrm{ml}$ before the adherence assay.

†Sugars were added to the bacterial suspension at a concentration of $250 \mu \mathrm{g} / \mathrm{ml}$.

the low calcium medium and in those induced to differentiate, the inhibition rates were less than $40 \%$. Limited inhibition by GalNAc was observed in the adherence of strain U-60 to both types of epidermal cells. GlcNAc also caused limited inhibition of adherence of strain U-60 to differentiated cells and of strain O-42 to undifferentiated cells. NANA slightly inhibited the adherence of the three strains used except for that of strain U-9-1 to undifferentiated cells. 


\section{Discussion}

Epidermal cells grow and differentiate from basal cells to corneocytes, and then exfoliate as squames in due course. Bacterial adherence to epidermal cells in various stages may differ, because of differences in surface characteristics. Since $S$. aureus is a common pathogen of the skin and mucous regions, its adherence to epidermal cells is of great interest. Bibel et al. (1982) examined skin and nasal epithelial cells, scraped from human volunteers, to which $S$. aureus adhered. When they classified epithelial cells morphologically by the degree of differentiation, i.e., spinous low granular, high granular and keratin cells, staphylococcal adherence correlated best with the degree of epithelial cell differentiation. S. aureus showed the greatest adherence to terminally differentiated keratin cells.

Cultured epidermal cell growth in standard medium, characterised by limited proliferation, stratification and terminal differentiation, can be altered by lowering the calcium concentration in the medium to $0.05 \mathrm{~mm}$. In low calcium medium, cells grow selectively as a monolayer with high proliferation rates. Attached cells retain many of the characteristics of basal cells; they have small polygonal shapes, undergo mitosis and express the pemphigoid antigen characteristic of basal cells (Yuspa et al., 1980). These cells can be induced to differentiate terminally by raising the calcium concentration of the medium up to $0.1 \mathrm{~mm}$ (high calcium medium). The sequential events following the switch to high calcium medium have been extensively studied (Hennings et al., 1980; Hennings and Holbrook, 1983). Cells begin to stratify and decrease their proliferation rates within 24$48 \mathrm{~h}$, with the appearance of keratohyalin granules, the degradation of nuclei, and the formation of a cornified cell envelope. Thus, cultured epidermal cell differentiation induced in vitro by calcium, employed in this study, mimics cell differentiation in vivo, although it is not exactly the same. Three out of 10 strains used in the present study adhered better to differentiated cells than to undifferentiated cells. The adherence of strain U-60, one of the three strains, correlated with the incubation time of

\section{REFERENCES}

Aly R, Maibach H I, Shinefield H R 1977 Microbial flora of atopic dermatitis. Archives of Dermatology 113: 780-782.

Aly R, Shinefield H R, Litz C, Maibach H I 1980 Role of teichoic acid in the binding of Staphylococcus aureus to epidermal cells in the high calcium medium, which induces cell differentiation. These data obtained with an in-vitro model support the results of Bibel et al. (1982). One strain, however, was more adherent to undifferentiated cells and the other six strains exhibited no difference, which suggest diversity of staphylococcal adherence to host cells. This in-vitro model of epidermal differentiation, which can be controlled easily, makes it possible to investigate the nature of epidermal cell surfaces to which bacteria adhere.

Beuth et al. (1988) reported the role of lectins in the adherence of $S$. saprophyticus to uroepithelial cells. GalNAc and NANA inhibited adherence the most, and it was suggested that they were involved in the adherence mechanism. Membrane sugars of epidermal cells change during differentiation (Nemanic et al., 1983). Therefore, the changes in staphylococcal adherence to epidermal cells during differentiation, may reflect changes in the sugars within the epidermal membrane. However, the sugars used in this experiment showed limited inhibition of adherence. It should be noted that we used only monosaccharides. Oligosaccharides exist on the epidermal cell surface and they might inhibit adherence to a greater degree than the monosaccharides utilised in this study.

LTA is one candidate cell surface component with which $S$. aureus may adhere to host tissues (Carruthers and Kabat, 1983). Most of the reports describing the role of LTA have been based on inhibition assays. Although there was limited inhibition of adherence by LTA, we could not exclude the possibility that LTA is involved in adherence of $S$. aureus. If bacteria possess more than two mechanisms for adherence, LTA could not be expected to inhibit completely.

Physicochemical forces, such as hydrophobic interactions, are involved in the mechanisms of bacterial adherence, as well as specific interactions (Fletcher and Loeb, 1979). Although these nonspecific forces may play roles in staphylococcal adherence, we could not find a relationship between the hydrophobicity of bacterial cells and adherence.

The results we report here warrant further investigation of staphylococcal adherence with controlled cultured cells as substrates.

nasal epithelial cells. Journal of Infectious Diseases 141 : 463 465.

Aly R, Levit S 1987 Adherence of Staphylococcus aureus to squamous epithelium : role of fibronectin and teichoic acid. Reviews of Infectious Diseases 9: S341-S350.

Beuth J, Ko H L, Ohshima Y, Yassin A, Uhlenbruck G, 
Pulverer G 1988 The role of lectins and lipoteichoic acid in adherence of Staphylococcus saprophyticus. Zentralblatt fur Bakteriologie, Mikrobiologie und Hygiene A 268: 357-361.

Bibel D J, Aly R, Shinefield H R, Maibach H I, Strauss W G 1982 Importance of the keratinized epithelial cell in bacterial adherence. Journal of Investigative Dermatology 79: 250-253.

Carruthers M M, Kabat W J 1983 Mediation of staphylococcal adherence to mucosal cells by lipoteichoic acid. Infection and Immunity 40: 444-446.

Fletcher M, Loeb G I 1979 Influence of substratum characteristics on the attachment of marine pseudomonad to solid surfaces. Applied and Environmental Microbiology 37: 6772.

Fuquay J I, Loo D T, Barnes D W 1986 Binding of Staphylococcus aureus by human serum spreading factor in an in vitro assay. Infection and Immunity 52: 714-717.

Hanahan D J, Olley J N 1958 Chemical nature of monophosphoinositides. Journal of Biological Chemistry 231 : 813-828.

Hennings H, Michael D, Cheng C, Steinert P, Holbrook K, Yuspa S H 1980 Calcium regulation of growth and differentiation of mouse epidermal cells in culture. Cell 19: 245-254.

Hennings H, Holbrook K A 1983 Calcium regulation of cell-cell contact and differentiation of epidermal cells in cultureAn ultrastructural study. Experimental Cell Research 143: 127-142.

Holderbaum D, Hall G S, Ehrhart L A 1986 Collagen binding to Staphylococcus aureus. Infection and Immunity 54: 356364.

Leyden J J, Marples R R, Kligman A M 1974 Staphylococcus aureus in the lesions of atopic dermatitis. British Journal of Dermatology 90 : 525-530.

Lopes J D, dos Reis M, Bretani R R 1985 Presence of laminin receptors in Staphylococcus aureus. Science 229: 275-277.

Lowry O H, Roberts N R, Leiner K Y, Wu M-L, Farr A L 1954 The quantitative histochemistry of brain. Journal of Biological Chemistry 207: 1-17.

Maxe I, Rydén C, Wadström T, Rubin K 1986 Specific attachment of Staphylococcus aureus to immobilized fibronectin. Infection and Immunity 54: 695-704.

Minagi S, Miyake Y, Akagawa Y, Tsuru H, Suginaka H $1986 a$ Effect of saliva on candidal adherence to polymethyl methacrylate resin. Hiroshima Journal of Medical Sciences 35: 93-97.

Minagi S, Miyake Y, Fujioka Y, Tsuru H, Suginaka H $1986 b$ Cell-surface hydrophobicity of Candida species as determined by the contact-angle and hydrocarbon-adherence methods. Journal of General Microbiology 132: 1111-1115.

Miyake Y, Kohada A, Fujii I, Sugai M, Suginaka H 1989 Aminoglycosides enhance the adherence of Staphylococcus aureus to HeLa cells. Journal of Antimicrobial Chemotherapy 23: $79-86$.

Nemanic M K, Whitehead J S, Elias P M 1983 Alterations in membrane sugars during epidermal differentiation: visualization with lectins and role of glycosidases. Journal of Histochemistry and Cytochemistry 31 : 887-897.

Ray T L, Wuepper K D 1976 Experimental cutaneous candidiasis in rodents. Journal of Investigative Dermatology 66: $29-33$

Ray T L, Payne C D 1988 Scanning electron microscopy of epidermal adherence and cavitation in murine candidiasis: a role for Candida acid proteinase. Infection and Immunity 56: $1942-1949$.

Rosenberg M, Gutnick D, Rosenberg E 1980 Adherence of bacteria to hydrocarbons: a simple method for measuring cell-surface hydrophobicity. FEMS Microbiology Letters 9: 29-33.

Rydén C, Rubin K, Speziale P, Höök M, Lindberg M, Wadström T 1983 Fibronectin receptors from Staphylococcus aureus. Journal of Biological Chemistry 258: 3396-3401.

Sugai M, Enomoto T, Miyake Y, Suginaka H 1987 Extracellular products of Staphylococcus aureus reversibly inhibit the terminal differentiation of cultured mouse epidermal cells. Cell Structure and Function 12: 395-399.

Yuspa S H, Hawley-Nelson P, Stanley J R, Hennings H 1980 Epidermal cell culture. Transplantation Proceedings 12 Suppl $1: 114-122$ 